Олексій Тогочинський, доктор педагогічних наук, доиеент, професор кафедри педагогіки та гуманітарних дисииплін, ректор Академії Державної пенітенціарної служби

\title{
ЗДОРОВ'ЯЗБЕРЕЖУВАЛЬНА КОМПЕТЕНТНІСТЬ ЯК СВІТОГЛЯДНА ОРІЄНТАЦІЯ МАЙБУТНІХ ПРАЦІВНИКІВ ПЕНІТЕНЦІАРНОЇ СИСТЕМИ
}

У статті наведений теоретичний аналіз компетентнісного підходу у площині розвитку та формування особистісних якостей майбутніх працівників пенітенціарної системи в сфері здоров'язбереження, розкрито фактори, що негативно впливають на фізичне, психічне, соиіальне благополуччя співробітників установ виконання покарань. Проведений аналіз складових здоров'язбережувальної компетентності майбутніх працівників пенітенціарної системи дозволив виділити ї̈ компоненти, критерії та показники, а також визначити три рівні їх сформованості. Встановлено, щуо формуванню здоров 'язбережсувальної компетентності курсантів можуть сприяти освітні технологї.

Ключові слова: здоров'язбережувальна компетентність; компоненти здоров'язбережувальноі компетентності; курсанти; здоров'язбережувальні технологї; фактори впливу на здоров 'язбереження пенітенціарного працівника.

Табл. 2. Лім. 10.

Oleksiy Tohochynskiy, Doctor of Sciences (Pedagogy), Associate Professor, Professor of the Pedagogics and Humanitarian Disciplines Department, Rector of the Academy of State Penitentiary Service

\section{HEALTH-SAVING COMPETENCE AS AN OUTLOOKING ORIENTATION OF FUTURE EMPLOYEES OFTHE PENETIARY SYSTEM}

The theoretical analysis of the competence approach in the area of development and formation of personal qualities of future employees of the penitentiary system in the sphere of health-saving is given in the article. The factors that negatively affect the physical, psychological, and social well-being of the employees of penal institutions are disclosed. It is stated that the health-saving competence of future employees of the penitentiary system is a combination of knowledge and skills used by an individual in order to plan a life path by keeping a good physical form, stress and professional diseases preventing, a healthy lifestyle and nutrition, spiritual culture and adequate self-esteem of health, developing of personal qualities that promote effective interaction. The maintained analysis of the parts of health-saving competence of future employees of the penitentiary system made it possible to distinguish its components, criteria and indicators, and also to determine three levels of their formation. It has been revealed that the formation of the cadets' health-saving competence can be facilitated by educational technologies (they are: organizing of educational process in higher educational institutions; developing of installations, skills and motivation to follow a healthy lifestyle, form of skills of professional interaction; designing of the program of professional and personal growth), based on the principles (the principle of the cadets' conscious attitude towards the acquisition of health-saving technologies; the principle of the cadet's mastering the knowledge, skills and abilities that contribute to healthy lifestyle, the principle of forming the cadets' motivation concerning revealing activity in studying and after-classes activity, the principle of the cadets'systematic conduct of healthy lifestyle, the principle of ensuring the harmonious of physical and intellectual development of the cadet's personality; the principle of the cadet's responsible attitude both to his own health and to saving of the health of the others) and the methods and forms of classes conducting.

Keywords: health-saving competence;components of health-saving competence; cadets; health-saving technologies; factors influencing on health-saving of a penitentiary employee.

П остановка проблеми. Професійна діяльність пенітенціарного персоналу в середовищі, що характеризується сукупністю негативних факторів, які впливають на появу професійної деформації, загрозу фізичному та психічному здоров'ю, обумовлює потребу в оволодінні майбутніми співробітниками здоров'язберігаючою компетентністю, яка виступає своєрідним запобіжником, що дозволяє зменшити силу стресу, створює передумови для підтримки психічного та соматичного здоров'я пенітенціарного працівника, що є достатньо актуальним і потребує всебічного розгляду.

Аналіз основних досліджень і публікацій. Здоров'язберігаючі технології в частині впливу комп'ютеризації на освітній процес досліджували О. Пилипишин [8], С. Луканьова, Р. Бойчук, С. Селіверстов, М. Лютик [6] та ін. Дослідженню 


\section{ЗДОРОВ'ЯЗБЕРЕЖУВАЛЬНА КОМПЕТЕНТНІСТЬ ЯКС СВТОГЛЯДНА ОРІЄНТАЦІЯ МАЙБУТНІХПРАЦІВНИКІВПЕНІТЕНЦАРНОӤСИСТЕМИ}

фізичної культури як засобу впливу на здоров'язбереження присвячені публікації О. Кучерявого [5] та ін. Психологічні засади реалізації здоров'язбережувальних технологій в закладах освіти були предметом досліджень О. Ващенко, С. Свириденко [3] та ін. У соціальнопсихологічному аспекті здоров'язбережувальну компетентність студентів як основу його культури досліджували Н. Башавець [1], Д. Воронін [4] та ін. Здоровий спосіб життя як важливу складову професійної підготовки майбутнього вчителя цікавили Т. Панасенко [7] та ін.
Одним із завдань підготовки майбутніх працівників пенітенціарної системи до подальшої професійної діяльності $\epsilon$ набуття ними здоров'язбережувальної компетентності. Опитування 103 працівників Державної кримінально-виконавчої служби України, які проходили курси підвищення кваліфікації в Академії Державної пенітенціарної служби, дозволило виявити фактори впливу на здоров'язбереження співробітника, що пов'язані із його соматичним, психічним та соціальним здоров'ям і представити їх у табл.1.

Фактори, що впливають на здоров'язбереження співробітника

Таблиця 1. установи виконання покарань

\begin{tabular}{|c|c|}
\hline Види здоров’я & Фактори впливу на здоров’язбереження співробітника \\
\hline Соматичне & $\begin{array}{l}\text { шкідливі звички (алкоголь, куріння); порушення режиму харчування; неправильне } \\
\text { харчування; малорухомий спосіб життя; погана профілактика професійних } \\
\text { захворювань; низький рівень медичної допомоги; зловживання лікарськими } \\
\text { препаратами; контакти з людьми, які є носіями соціально-небезпечних } \\
\text { захворювань; санітарно-гігієнічний режим праці; травми тощо }\end{array}$ \\
\hline $\begin{array}{l}\text { Психічне та } \\
\text { духовне }\end{array}$ & $\begin{array}{l}\text { конфлікти; агресивне оточення; психічне навантаження через необхідність } \\
\text { толерантного ставлення до осіб, які здійснили аморальні злочини, є маргіналами; } \\
\text { стресові ситуації; психологічний тиск } 3 \text { боку засуджених; нездатність до } \\
\text { самоконтролю та саморегуляції психічних станів; невпевненість у своїх силах тощо }\end{array}$ \\
\hline Соціальне & $\begin{array}{l}\text { відсутність взаєморозуміння та співробітництва з колегами; напружені } \\
\text { психоемоційні відносини } 3 \text { оточуючими; проблеми соціального характеру (сімейні, } \\
\text { житлові умови; невеликий розмір грошового забезпечення); невміння приймати } \\
\text { рішення та діяти в нестандартних ситуцціях; неможливість реалізувати життєві } \\
\text { плани; негативне ставлення до виконання службових обов'язків тощо }\end{array}$ \\
\hline
\end{tabular}

Виділення невирішених раніше частин загальної проблеми. У результаті аналізу праць науковців виявлена суперечність між потребами Державної кримінально-виконавчої служби України упрацівниках здатних протистояти через здоров'язберігаючу компетентність впливам факторів, що негативно впливають на їх фізичне та психічне благополуччя та відсутністю науково обгрунтованих підходів щодо використання форм, методів, технологій для формування здоров'язбережувальної компетентності та особистісних якостей майбутніх працівників пенітенціарної системи в сфері збереження здоров'я упроцесі навчання в закладі вищої освіти (далі-3ВО).

Метою статті є теоретичний аналіз здоров'язбережувальної компетентності майбутніх працівників пенітенціарної системи та визначення технологій, принципів і методів формування iï компонентів, а також критеріїв $\mathrm{i}$ показників, що дозволяють оцінити рівні їі сформованості.

Виклад основного матеріалу дослідження. Як правило, науковці відносять до складових здоров’я людини фізичне, психічне, моральне, духовне, соціальне [9].
Наведені в табл. 1 фактори можна класифікувати на зовнішні та внутрішні. Зовнішні фактори - це умови, що спричиняють ризики для здоров'я співробітника і не залежать від нього (низький рівень медичної допомоги; санітарногігієнічний режим праці; контакти з людьми, які $є$ носіями соціально-небезпечних захворювань; відсутність індивідуальних засобів захисту та ін.), а внугрішні фактори - це ставлення співробітника до власного здоров'я, його можливості, мотивація, світогляд, звички, поведінка та ін.

Формування здоров' язбережувальної компетентності укурсантів, під час навчання в ЗВО, можливе завдяки використанню певних методів, технологій і форм навчання, що обумовлює необхідність їх теоретичного дослідження.

О. Пилипишин здоров'язберігаючі освітні технології поділяє на три групи: організаційнопедагогічні (сприяють запобіганню станів перевтомлення, гіподинамії тощо); психологопедагогічні (робота на занятті); навчально-виховні (програми 3 формування культури здоров'я, навчання навичок здорового способу життя, профілактики шкідливих звичок, захворювань тощо). При цьому, наводить дві групи методів, 


\section{ЗДОРОВ'ЯЗБЕРЕЖУВАЛЬНА КОМПЕТЕНТНІСТЬ ЯК СВІТОГЛЯДНА ОРІЄНТАЦІЯ МАЙБУТНІХПРАЦІВНИКІВПЕНІТЕНЦАРНӦ̈СИСТЕМИ}

що дозволяють використати ці технології: специфічні та загально-педагогічні. До структури цих методів відносить прийоми (профілактичнозахисні, компенсаторно-нейтралізуючі, стимулюючі, інформаційно-навчальні) $[8,148]$. На думку науковця у студентів мають бути сформовані компетентності, як-от: здоров'язберігаюча; соціальна; життєтворча; інформаційна.

Н. Башавець в основу здоров'язберігаючої компетентності покладає фізичне виховання, що, на його думку, дозволяє сформувати у студента знання про теоретико-методичні основи здоров'язбереження та необхідність саморозвитку та самовдосконалення власної культури здоров'язбереження як світоглядної орієнтації, що грунтується на профілактиці професійних захворювань та подоланні стресу, оздоровчих заходах, розвитку морально-вольових якостей, основах саморегуляції, важливості усвідомлення підтримання активного фізичного стану, вмінні розробляти індивідуальну оздоровчу систему та вести здоровий спосіб життя, адекватно реагувати на вчинки оточуючих та об'єктивно оцінювати стан свого фізичного здоров'я, володіти методиками самоконтролю та самооцінки стану здоров'я [1, $121-122]$.

Формувати стійку мотивацію у студентів до збереження здоров'я через засоби фізичного виховання та спорту, медично-валеологічну інформативність, організацію їх життєдіяльності пропонує Д. Воронін [4, 28].

Т. Бондаренко докомпонентів здоров' язбережувальної компетентності відносить когнітивний, емоційноціннісний та практично-діяльнісний компоненти [2].

Т. Панасенко, досліджуючи формування здоров'язбережувальної компетентності майбутніх учителів, також виокремлює у іiі структурі “три основні компоненти:

- когнітивний (система знань і пізнавальних вмінь);

- особистісний (наявність і прояв рис особистості, зумовлених характером діяльності 3 формування здорового способу життя свого та інших людей);

- діяльнісний (здатність обгрунтовано виявляти та раціонально застосовувати шляхи і засоби для найбільш ефективного досягнення мети)" [7, 131].

Викладене вище дозволяє стверджувати, що здоров'язбережувальну компетентність майбутніх працівників пенітенціарної системи можна розглядати як сукупність знань та вмінь, що використовуються особистістю для планування життєвої траєкторії через підтримку хорошої фізичної форми, профілактику стресу та професійних захворювань, здоровий спосіб життя та харчування, духовну культуру й адекватну самооцінку стану здоров'я, розвиток особистісних якостей, які сприяють ефективній взаємодії.

Компонентами здоров'язбережувальної компетентності майбутніх працівників пенітенціарної системи, критеріями та показниками, що дозволяють визначити рівень їх сформованості (низький, середній та високий) приймаємо:

- мотиваційний компонент - наявність мотивації щодо ведення здорового способу життя. Критерієм виступає усвідомлення курсантом потреби здоров'язбереження як основи повноцінного існування, а показниками бажання розвивати особистісні якості (відповідальність; витривалість; впевненість; наполегливість; послідовність; самодисципліна; самовіддача; стабільність; цілеспрямованість та ін.), що сприяють здоров'язбереженню; прагнення дотримуватись здорового способу життя та цікавитись станом власного здоров'я;

- когнітивний компонент - наявність знань про сутність здоров'язбереження. Критерієм когнітивного компоненту є наявність знань про складники здоров'язбереження, а показниками виступають: знання про профілактику та зменшення ризику розвитку професійних захворювань; знання про наслідки впливу стресу на організм людини; знання про методи та засоби підтримки здоров' я співробітника;

- діяльнісний компонент - наявність умінь щодо профілактики захворювань та ведення здорового способу життя. Критерієм діяльнісного компоненту виступає уміння дбайливо ставитися до власного здоров'я та здоров'я оточуючих, а показниками є: дотримання режимів відпочинку та сну, харчування, регулярних занять фізичною культурою та спортом, санітарно-гігієнічних вимог; здатність нейтралізувати вплив на здоров’я негативних чинників та звичок; вміння безконфліктно взаємодіяти 3 оточуючими та створювати умови для забезпечення динамічної безпеки; уміння оцінювати стан власного здоров'я і своєчасно вживати необхідних заходів для його поліпшення.

Діагностичним інструментарієм для оцінювання рівнів сформованості зазначених компонентів $є$ тести, опитувальники, спостереження.

Оцінювання рівнів сформованості компонентів здоров’ язберігаючої компетентності майбутніх працівників пенітенціарної системи 3 використанням описаних критеріїв та показників представлено в табл. 2. 
Таблиця 2.

Рівні сформованості компонентів здоров'язбережувальної компетентності майбутніх працівників пенітенціарної системи

\begin{tabular}{|c|c|c|c|}
\hline \multirow[t]{2}{*}{ Компонент } & \multicolumn{3}{|c|}{ Рівень сформованості } \\
\hline & високий & середній & низький \\
\hline Мотиваційний & $\begin{array}{l}\text { Сформована стійка } \\
\text { мотивація до } \\
\text { здоров’язбереження. } \\
\text { Постійне бажання } \\
\text { розвивати особистісні } \\
\text { якості, що сприяють } \\
\text { здоров’язбереженню. } \\
\text { Бажання постійно вести } \\
\text { здоровий спосіб, стежити } \\
\text { за станом власного } \\
\text { здоров’я. }\end{array}$ & $\begin{array}{l}\text { Існує мотивація до } \\
\text { здоров’язбереження, але } \\
\text { ці мотиви не } є \\
\text { домінуючими. Є } \\
\text { розуміння необхідності } \\
\text { розвивати особистісні } \\
\text { якості, що сприяють } \\
\text { здоров'язбереженню. Є } \\
\text { розуміння щодо } \\
\text { необхідності ведення } \\
\text { здорового способу } \\
\text { життя, контролю за } \\
\text { станом власного } \\
\text { здоров’я. }\end{array}$ & $\begin{array}{l}\text { Мотивація до здоро- } \\
\text { в'язбереження слабка. } \\
\text { Відсутнє розуміння } \\
\text { необхідності розвивати } \\
\text { особистісні якості, що } \\
\text { сприяють } \\
\text { здоров' язбереженню. Не } \\
\text { має розуміння щодо } \\
\text { необхідності ведення } \\
\text { здорового способу життя, } \\
\text { контролю за станом } \\
\text { власного здоров’я. }\end{array}$ \\
\hline Когнітивний & $\begin{array}{l}\text { Міцні знання про } \\
\text { складники здоров’я- } \\
\text { збереження та } \\
\text { профілактику ризику } \\
\text { розвитку професійних } \\
\text { захворювань. Глибокі } \\
\text { знання про наслідки } \\
\text { впливу стресу на } \\
\text { організм людини, методи } \\
\text { та засоби підтримки } \\
\text { здоров’я співробітника. }\end{array}$ & $\begin{array}{l}\text { Хороші знання про } \\
\text { складники здоров'я- } \\
\text { збереження та } \\
\text { профілактику ризику } \\
\text { розвитку професійних } \\
\text { захворювань. Хороші } \\
\text { знання про наслідки } \\
\text { впливу стресу на } \\
\text { організм людини, методи } \\
\text { та засоби підтримки } \\
\text { здоров’я співробітника. }\end{array}$ & $\begin{array}{l}\text { Відсутність знань про } \\
\text { складники здоров'я- } \\
\text { збереження та } \\
\text { профілактику ризику } \\
\text { розвитку професійних } \\
\text { захворювань. Погані } \\
\text { знання про наслідки } \\
\text { впливу стресу на організм } \\
\text { людини, методи та засоби } \\
\text { підтримки здоров’я } \\
\text { співробітника. }\end{array}$ \\
\hline Діяльнісний & $\begin{array}{l}\text { Розвинене уміння } \\
\text { дбайливо ставитися до } \\
\text { власного здоров'я та } \\
\text { здоров’я } \\
\text { оточуючих; регулярне } \\
\text { дотримання режимів } \\
\text { відпочинку та сну, } \\
\text { харчування, занять } \\
\text { фізичною культурою та } \\
\text { спортом; постійне } \\
\text { виконання санітарно- } \\
\text { гігієнічних вимог; } \\
\text { відсутність негативних } \\
\text { звичок; розвинене вміння } \\
\text { безконфліктно } \\
\text { взаємодіяти з } \\
\text { оточуючими та } \\
\text { створювати умови для } \\
\text { забезпечення динамічної } \\
\text { безпеки; розвинене } \\
\text { уміння оцінювати стан } \\
\text { власного здоров'я і } \\
\text { своєчасно вживати } \\
\text { необхідних заходів для } \\
\text { його поліпшення. }\end{array}$ & $\begin{array}{l}\text { Є уміння дбайливо } \\
\text { ставитися до власного } \\
\text { здоров'я та здоров'я } \\
\text { оточуючих; мають } \\
\text { місце випадки } \\
\text { порушення режимів } \\
\text { відпочинку та сну, } \\
\text { харчування, занять } \\
\text { фізичною культурою та } \\
\text { спортом; виконання } \\
\text { санітарно-гігієнічних } \\
\text { вимог здійснюється, але } \\
\text { не завжди; серед } \\
\text { негативних звичок є } \\
\text { куріння; вміє переважно } \\
\text { безконфліктно } \\
\text { взаєодіяти з } \\
\text { оточуючими та } \\
\text { створювати умови для } \\
\text { забезпечення динамічної } \\
\text { безпеки; уміє оцінювати } \\
\text { стан власного здоров’я; } \\
\text { необхідні заходи для } \\
\text { поліпшення здоров’я } \\
\text { вживає після } \\
\text { проходження щорічного } \\
\text { медичного профогляду. }\end{array}$ & $\begin{array}{l}\text { Відсутнє уміння дбайливо } \\
\text { ставитися до власного } \\
\text { здоров’я та здоров'я } \\
\text { оточуючих; } \\
\text { не дотримується режиму } \\
\text { відпочинку та сну, } \\
\text { харчування; не займається } \\
\text { фізичною культурою та } \\
\text { спортом; не виконує } \\
\text { санітарно-гігієнічні } \\
\text { вимоги; мають місце } \\
\text { негативні звички; не вміє } \\
\text { безконфліктно } \\
\text { взаємодіяти з } \\
\text { оточуючими та } \\
\text { створювати умови для } \\
\text { забезпечення динамічної } \\
\text { безпеки; не уміє } \\
\text { оцінювати стан власного } \\
\text { здоров’я; не вживає } \\
\text { необхідні заходи для } \\
\text { поліпшення здоров’я } \\
\text { навіть після проходження } \\
\text { щорічного медичного } \\
\text { профогляду. }\end{array}$ \\
\hline
\end{tabular}

О. Третяк та О. Шеремета також вказують на майбутніх працівників пенітенціарної системи те, що “Важливу роль у формуванні особистості відіграє мотивація та спрямованість, які 


\section{ЗДОРОВ'ЯЗБЕРЕЖУВАЛЬНА КОМПЕТЕНТНІСТЬ ЯК СВІТОГЛЯДНА ОРІЕНТАЦИЯ МАЙБУТНІХПРАЦІВНИКІВПЕНІТЕНЦАРНОӤСИСТЕМИ}

дозволяють долати труднощі та орієнтують на здобуття знань, умінь та навичок необхідних у подальшій професійній діяльності. Формування особистості курсанта в Академії пов'язана 3 процесом активного включення в нове середовище, усвідомленням сутності вимог, напрацюванням моделей поведінки та звичок, виконанням соціальних ролей командирів та підлеглих, самостійністю та відповідальністю за власні дії та вчинки" [10, 500].

Погоджуючись 3 вище викладеним необхідно зазначити, що на появу мотивації і спрямованості курсанта та розвиток особистісних якостей, що сприяють здоров' язбереженню, здійснюють вплив як внугрішні, так і зовнішні чинники, які безумовно взаємопов'язані та грунтуються на певних принципах та технологіях. Зокрема, проведений аналіз здоров'язбережувальних технологій дозволив виділи ті, що можуть бути використані в освітньому процесі в 3ВО, а також відповідні ним методи, форми і принципи роботи. Зокрема, до таких технологій можна віднести як-от:

- технологію організації освітнього проиесу в 3BO, в основу якої покладений підхід, що забезпечує оптимальне розумове, психічне та фізичне навантаження курсантів (здатність до оптимального розподілу часу; вміння поєднувати розумове та фізичне навантаження; належні умови для навчання та відпочинку; виконання санітарногігієнічних норм та ін.);

- технологію вироблення установок, навичок та мотивації щзодо ведення здорового способу життя (ранкові зарядки; регулярні відвідування спортивних секцій; дотримання правил особистої гігієни; відмова від шкідливих звичок; збалансоване харчування; медичні огляди; профілактика травматизму та ін.), яка знижує ризики та вразливість курсантів на захворювання;

- технологію формування навичок професійної взаємодії (вміння налагоджувати контактну взаємодію з різними категоріями засуджених; здатність здійснювати профілактикута подолання конфліктів та агресії; вміння зменшувати вплив стресу та ризик прояву професійної деформації; здатність до управління психічними станами; розвиток аналітичного та критичного мислення; навички про-соціального моделювання та забезпечення динамічної безпеки; вміння попереджувати та розв'язувати конфлікти; навички ефективної командної роботи; вміння самостійно виражати ідеї, досвід та почуття; вміння вислуховувати, відстоювати власну позицію та застосовувати аргументацію; здатність отримувати та використовувати інформацію; здатність організовувати культуромовне середовище та ін.);

- технологію проектування програми професійно-особистісного зростання (здатність до розробки планів особистісного зростання; планування та проведення аналізу роботи пов'язаної із здоров'язбереженням; планування регулярного ведення здорового способу життя та зміцнення здоров'я своїх рідних та інших людей; планування створення безпечних умов життєдіяльності; здатність займати та відстоювати активну позицію 3 питань здоров'язбереження; планування відвідування фізкультурно-оздоровчих центрів, спортивних секцій; планування розвитку особистісних якостей, що впливають на ведення здорового способу життя; моніторинг стану здоров'я та планування роботи щодо здоров'ябереження та iH.).

До принц̧ипів, що лежать в основі використання зазначених технологій можна віднести такі, як: принцип свідомого ставлення курсантів до оволодіння здоров'язберігаючими технологіями; принцип оволодіння курсантами знаннями, вміннями та навичками, що сприяють веденню здорового способу життя; принцип формування мотивації у курсантів щодо прояву активності у навчанні та в поза навчальній діяльності; принцип систематичності у веденні здорового способу життя курсантами; принцип забезпечення гармонійного фізичного та інтелектуального розвитку особистості курсанта; принцип відповідального ставлення курсанта як до власного здоров'я, так і до збереження здоров'я оточуючих.

Серед методів та форм формування здоров'язбережувальної компетентності курсантів відносимо:

- словесні методи: бесіди, лекції на теми здоров'язбереження, що проводяться як під час викладання навчальних дисциплін науковопедагогічними працівниками, а також кураторами та курсовими офіцерами. Лекції, вікторини, дискусії, круглі столи та інші форми роботи із запрошенням провідних спеціалістів-практиків, лікарів, представників державних і недержавних організацій, які надають інформацію щодо негативних факторів впливу на здоров'я людини та формують мотивацію до здорового способу життя;

- практичні методи: просвітницька та волонтерська робота курсантів за принципом “рівний - рівному” в закладах середньої освіти, виховних колоніях для неповнолітніх; заходи в межах тижня права; робота в юридичній клініці; 


\section{ЗДОРОВ'ЯЗБЕРЕЖУВАЛЬНА КОМПЕТЕНТНІСТЬ ЯК СВІТОГЛЯДНА ОРІЄНТАЦІЯ МАЙБУТНІХПРАЦІВНИКІВ ПЕНІТЕНЦАРНОЇСИСТЕМИ}

розвиток рухових якостей; виконання вправ; тренування; ранкова зарядка; ігри (рольові ігри, ділові ігри, ситуативні завдання - для моделювання ситуацій, що вимагають від курсантів прояву знань, умінь та навичок, емоційного ставлення для розв'язання життєвих ситуацій, що можуть викликати стреси, впливати на соматичне та психічне здоров'я);

- наочні методи: спеціальні навчальні фільми; плакати; макети; журнали; брошури; кліпи; газети; відеоролики; телебачення тощо, в яких представлені приклади поведінки людини, яка впливає на стан іiї здоров'я; екскурсії до медичних установ;

- пізнавальні методи: проблемне викладення матеріалу; евристичні навчально-дослідні завдання та ін.

- стимулюючі методи: формування почуття професійного обов'язку та відповідальності за власні дії та вчинки; моніторинг сформованих знань, вмінь та навичок 3 питань здоров'язбереження та ін.

Отже, період навчання курсанта у ЗВО дозволяє створити умови для розвитку особистісних якостей, які визначають світоглядну орієнтацію майбугнього працівника пенітенціарної системи та сприяють формуванню у нього здоров' язбережувальної компетентності.

Висновки та перспективи подальших досліджень.

Проведений аналізскладових здоров'язбережувальної компетентності майбутніх працівників пенітенціарної системи дозволив виділити їі компоненти (мотиваційний, когнітивний, діяльнісний), критерії та показники, а також визначити три рівні (високий, середній, низький) їх сформованості. Встановлено, що розвитку особистісних якостей (відповідальність; витривалість; впевненість; наполегливість; послідовність; самодисципліна; самовіддача; стабільність; цілеспрямованість та ін.) та формуванню здоров'язбережувальної компетентності курсантів можуть сприяти освітні технології (організації освітнього процесу в ЗВО; вироблення установок, навичок та мотивації щодо ведення здорового способу життя; формування навичок професійної взаємодії; проектування програми професійно-особистісного зростання), в основу яких покладено принципи та методи (словесні, практичні, наочні, пізнавальні, стимулюючі) та форми проведення навчальних занять (дискусія, вікторина, круглий стіл, ситуаційно-рольова гра та ін.).

Предметом подальших досліджень є розробка моделі формування здоров'язбережувальної компетентності майбутніх працівників пенітенціарної системи та перевірка ¥ї ефективності в умовах ЗВО.

\section{ЛІТЕРАТУРА}

1. Башавець Н. А. Здоров'язбережувальна компетентність майбутнього фахівця як основа його культури / Н. А. Башавець // Наука і освіта. Педагогіка. - Одеса, 2013. - №1-2. - С. 120-122.

2. Бондаренко Т. С. Визначення структури здоров'язберігаючої компетентності майбутніх вчителів біології / Т. Є. Бондаренко // Педагогічні науки: теорія, історія, інноваційні технології. Суми, 2012. - № 1(19). - С. 214-223.

3. Ващенко О. Готовність вчителя до використання здоров'язбережувальних технологій у навчально-виховному процесі / О. Ващенко, С. Свириденко С. // Здоров'я та фізична культура. - № 8. - 2006.- С.1-6.

4. Воронін Д. Є. Здоров'язберігаюча компетентність студента в соціальнопедагогічному аспекті / Д. С. Воронін // Педагогіка, психологія та медико-біол. пробл. фіз. виховання і спорту. - № 2. - 2006. - С. 25-28.

5. Кучерявий О. Г. Культура здоров'я як цілісна властивість особистості й складова частина її загальної культури / О. Г. Кучерявий // Науковий вісник Південноукраїнського національного педагогічного університету ім. К. Д. Ушинського. - Одеса. - 2011. - № 9-10. С. 121-126.

6. Луканьова С. М. Формування культури здоров'язбереження як світоглядної орієнтації студентів ВНЗ в умовах ком'ютерізації навчання / С. М. Луканьова, Р. Р. Бойчук, С. І. Селіверстов, М. Д. Лютик // Молодий вчений. - Херсон. 2017. - № 3.1 (43.1). - С. 198-201.

7. Панасенко Т. В. Формування здоров'язберігаючої компетентності майбугніх вчителів початкової школи у ВНЗ I-II p.a. / Т. В. Панасенко // Молодий вчений. - Херсон. - № 9.1 (36.1) вер., 2016 р. С. $130-134$.

8. Пилипишин О. I. Здоров'язберігаючі технології в організації навчально-виховного процесу в закладах освіти: теоретичний аналіз / O.I. Пилипишин // Науковий вісник Ужгородського національного університету. Серія: Педагогіка. Соціальна робота. - Ужгород. - 2015. - Вип. 35. - C. 147-151.

9. Тагліна О.В. Основи здоровя : підруч. / О. В. Тагліна. - Х. : Вид-во “Ранок", 2017. - 160 с.

10. Третяк О. С. Формування особистості майбутніх працівників пенітенціарної системи в Академії Державної пенітенціарної служби. / О. С. Третяк, О. П. Шеремета / Освітньо-наукове забезпечення діяльності складових сектору 
безпеки і оборони України: [тези доп. XI Всеукр. наук.-практ. конф. 15 лис. - 2018, м. Хмельницький] / Національна акад. Держ. прикордонної служби України ім. Б. Хмельницького. - Хмельницький, 2018. - С.499501.

\section{REFERENCES}

1. Bashavets, N. A. (2013). Zdoroviazberezhuvalna kompetentnist maibutnoho fakhivtsia yak osnova yoho kultury [Health-saving competence of a future specialist as the basis of his culture]. Science and education. Pedagogy. No. 1-2, pp. 120-122. [in Ukrainian].

2. Bondarenko, T. Ye. (2012). Vyznachennia struktury zdoroviazberihaiuchoi kompetentnosti maibutnikh vchyteliv biolohii [Determination of health structure of health-saving competence of future teachers of biology]. Pedagogical sciences: theory, history, innovation technology. Sumy. No.1(19), pp. 214-223. [in Ukrainian].

3. Vashchenko, O. \& Svyrydenko S. (2006). Hotovnist vchytelia do vykorystannia zdoroviazberezhuvalnykh tekhnolohii u navchalnovykhovnomu protsesi [Readiness of a teacher to use health-saving technologies in the educational process]. Health and culture. No. 8, pp.1-6. [in Ukrainian].

4. Voronin, D. Ye. (2006). Zdoroviazberihaiucha kompetentnist studenta $\mathrm{v}$ sotsialno-pedahohichnomu aspekti [Health-saving competence of a student in social and pedagogical aspect]. Pedagogy, psychology and medical biologic problems and physical training and sport. No. 2, pp. 25-28. [in Ukrainian].

5. Kucheriavyi, O. H. (2011). Kultura zdorovia yak tsilisna vlastyvist osobystosti y skladova chastyna yii zahalnoi kultury [Culture of health as an integral quality of an individual and an integral part of its general culture]. Scientific Herald of the Southern Ukrainian National Pedagogical University named after Kostyantyn Ushynskiy.No. 9-10, pp. 121-126. [in Ukrainian].
6. Lukanova, S. M., Boichuk, R. R., Seliverstov, S. I., \& Liutyk, M. D. (2017). Formuvannia kultury zdoroviazberezhennia yak svitohliadnoi oriientatsii studentiv VNZ v umovakh komiuterizatsii navchannia [Formation of a culture of health-saving as anoutlookingorientation of the students of higher educational establishment in conditions of computerization of studying]. Young scientist. No. 3.1 (43.1), pp. 198-201. [in Ukrainian].

7. Panasenko, T. V. (2016). Formuvannia zdoroviazberihaiuchoi kompetentnosti maibutnikh vchyteliv pochatkovoi shkoly u VNZ I-II r.a. [Formation of the health-saving competence of future primary school teachers athigher educational institutions of the I-II 1.a.]. Young scientist. No. 9.1 (36.1), pp. 130-134. [in Ukrainian].

8. Pylypyshyn, O. I. (2015). Zdoroviazberihaiuchi tekhnolohii v orhanizatsii navchalno-vykhovnoho protsesu v zakladakh osvity: teoretychnyi analiz [Health-saving technologies in the organization of educational process in educational institutions: theoretical analysis]. Scientific herald of Uzhhorod National University. Series: Pedagogy. Social work. Vol. 35, pp. 147-151. [in Ukrainian].

9. Tahlina, O. V. (2017). Osnovy zdorovia: pidruch. [The bases of health]. Kharkiv : "Ranok" Publ., 160 p. [in Ukrainian].

10. Tretiak, O. S. \& Sheremeta, O. P. (2018). Formuvannia osobystosti maibutnikh pratsivnykiv penitentsiarnoi systemy v Akademii Derzhavnoi penitentsiarnoi sluzhby [Formation of the personality of future employees of the penitentiary system at the Academy of the State Penitentiary Service]. Osvitnonaukove zabezpecheniya diialnosti skladovykh sektoru bezpeky i oborony Ukrainy: tezy dop. KHI Vseukr. nauk.-prakt. konf.(m. Khmelnytskyi, 15 lys. 2018 r.). - The educational and scientific support of the components of the security and defense sector of Ukraine: theses of the reports of the XI All-Ukrainian Scientific and Practical Conference November 15, 2018. (pp.499-501). Khmelnytskyi.[in Ukrainian].

Стаття надійшла до редакції 19.12.2018

\title{
G5808NC2058080
}

“...наші знання ніколи не можуть мати кіния саме тому, що предмет пізнання нескінченний”.

\author{
Блез Tаскаль
} франиузький білособ, письменник

“ЛІільжи самоосвіта спроможна сбормувати справді ерудовану та всебічно розвинену особистість".

Жан-Жак Руссо франиузький білособ, просвітник

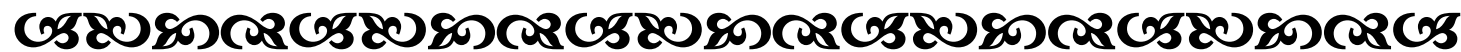

Молодь і ринок №1 (168), 2019 